"Assessment of the social and economic development of a region: essence, methodology and correlation with transparency of local authorities"

\begin{tabular}{|c|c|}
\hline AUTHORS & $\begin{array}{l}\text { Olga Liuta (D https://orcid.org/0000-0002-3165-7991 } \\
\text { Borys Mershchii (D https://orcid.org/0000-0002-4831-6907 } \\
\mathbb{R} \text { http://www.researcherid.com/rid//-7627-2018 }\end{array}$ \\
\hline ARTICLE INFO & $\begin{array}{l}\text { Olga Liuta and Borys Mershchii (2019). Assessment of the social and economic } \\
\text { development of a region: essence, methodology and correlation with } \\
\text { transparency of local authorities. Public and Municipal Finance, 8(1), 83-93. } \\
\text { doi:10.21511/pmf.08(1).2019.07 }\end{array}$ \\
\hline DOI & http://dx.doi.org/10.21511/pmf.08(1).2019.07 \\
\hline RELEASED ON & Saturday, 11 January 2020 \\
\hline RECEIVED ON & Sunday, 01 December 2019 \\
\hline ACCEPTED ON & Thursday, 19 December 2019 \\
\hline LICENSE & $\begin{array}{l}(c) \text { EY } \\
\text { This work is licensed under a Creative Commons Attribution } 4.0 \text { International } \\
\text { License }\end{array}$ \\
\hline JOURNAL & "Public and Municipal Finance" \\
\hline ISSN PRINT & $2222-1867$ \\
\hline ISSN ONLINE & $2222-1875$ \\
\hline PUBLISHER & LLC "Consulting Publishing Company "Business Perspectives" \\
\hline FOUNDER & LLC "Consulting Publishing Company "Business Perspectives" \\
\hline
\end{tabular}

NUMBER OF REFERENCES

21
NUMBER OF FIGURES

1
NUMBER OF TABLES

4

(C) The author(s) 2022. This publication is an open access article. 


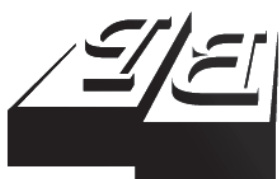

BUSINESS PERSPECTIVES

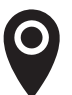

LLC "CPC "Business Perspectives" Hryhorii Skovoroda lane, 10, Sumy, 40022, Ukraine

www.businessperspectives.org

Received on: $1^{\text {st }}$ of December, 2019 Accepted on: $19^{\text {th }}$ of December, 2019

(C) Olga Liuta, Borys Mershchii, 2019

Olga Liuta, Ph.D., Department of Finance, Banking and Insurance, Sumy State University, Ukraine.

Borys Mershchii, Ph.D. Student, Department of Finance, Banking and Insurance, Sumy State University, Ukraine.

\section{ASSESSMENT OF THE SOCIAL AND ECONOMIC DEVELOPMENT OF A REGION: ESSENCE, METHODOLOGY AND CORRELATION WITH TRANSPARENCY OF LOCAL AUTHORITIES}

\begin{abstract}
The introduction of fiscal policy transparency practices in the contemporary local financial management system is one of the prerequisites for increasing the socio-economic development of regions. Creating a transparent budget environment contributes to a faster and more effective solution to the region's current problems. The lack of a sufficient level of budgetary transparency is a consequence of poor public interest consideration, which impedes the people's realization of their own democratic aspirations and freedoms.

The article is aimed at developing scientific and methodological approach to assessing the state of social and economic development of a region and comparing the estimates with the regions' transparency levels for 2016-2018. Integral assessment of socioeconomic development consists of four stages. It has been found out that the level of socio-economic development of regions does not correlate with the transparency level of regional policy. Public finance transparency assessment of Sumy city has shown that its population needs a higher level of information disclosure, use of the latest information channels, and creation of convenient forms of involvement in the budget process. The transparency evaluation results in the areas of budgeting, public procurement, disposal of property of the territorial community, etc. have been investigated. Besides, directions for improving Sumy local authorities' information policy are proposed to increase its transparency.
\end{abstract}

\section{Keywords}

budget, transparency, public finance, questionnaire (survey), community, sustainable development

JEL Classification P43, H72

\section{INTRODUCTION}

In contemporary market environment, an important task is to assess the social and economic development of regions. This task requires the use of reliable data on the status of particular socio-economic phenomena. Forming a data transparency policy is the basis for obtaining the necessary information. Providing conditions for a transparent budgetary environment is one of the tasks of local authorities, since the openness mechanisms allow identifying potential problems at an early stage. The lack of a sufficient level of budgetary transparency is an obstacle to the implementation of one of the principles of the budgetary system, namely, public disclosure and transparency. Balanced socio-economic development of the Ukraine's regions is the key to reducing social tension in society. Overcoming the disparities of regional development is also in the area of budget information transpar- 
ency, public participation in the budget process, the creation of mechanisms for public control over the spending of budget funds. The implemented principles of budgetary transparency bring the domestic budgetary system closer to international standards and increase public confidence in the reforms.

\section{LITERATURE REVIEW}

Socio-economic development studies have attracted considerable attention from the scientific community. The understanding of this category is broad because of its complexity and gradual change of needs of the society depending on its development. The problems of socio-economic development are urgent at all times, as society strives for the highest possible level of satisfaction of own needs.

The current paper considers several scientific interpretations of the category under discussion. For example, Babayev and Bychenko (2011) view socio-economic development as a complex process aimed at changing several components of social life: economic, political, and social. Shostak and Bondaruk (2002) share a similar view; in addition to the economic and social components, they emphasize environmental and humanitarian issues. According to Mikhailichenko (2004), the components of socio-economic development include budgetary, investment and social components, which, taken together, improve the region's potential. That is, each of the scientists considered, depending on the purpose of the study, may interpret the category under study in his/her own way.

The research on socio-economic development of the regions pays considerable attention to the budget component. This is because the budget provides most of the basic population needs and implements state social policy. In particular, Golikov (2012) explores the issues of budget financing for socio-economic development in the context of the current and prospective state of local government budget financing depending on changes in budget policy priorities. Pavlov (2007) stresses the importance of effective budget management in terms of achieving regional policy goals. Kushnirchuk (2010) considers tax aspects of the budgetary component of socio-economic development at the local level. Sound tax policy is assumed to be one of the key factors for improving the socio-economic development of a region. That is, the financial component of local socio-economic development, which is implemented using the budget toolkit, is more prioritized than other components. Therefore, a sufficient amount of financial resources is a prerequisite for the correct level of socio-economic development of the region.

A separate area of research on the socio-economic development of the regions concerns the role of local authorities in complex management of financial, social and other components to improve the living conditions of the population. In particular, Goncharova (2009) identifies socio-economic development with a process motivated by management measures of local authorities supported by higher level public authorities. Gubani (2011) views socio-economic development as a result of the local authorities' activities to ensure the economic viability of the territory. That is, the importance of optimal control is also one of the criteria for ensuring the effective socio-economic development of the regions.

In general, scientific community has no common vision regarding the components of socio-economic development of regions. Studying these components depends on the topic of the research trend chosen. Meanwhile, the separation of individual components results in a loss of complexity of the concept.

The article proposes to consider scientific approaches to developing the optimal methodology for constructing the socio-economic development index as a component of studying the regions' socio-economic development. The Institute for Demography and Social Research has developed its own methodology for assessing regional human development in 2012. This technique is used by the State Statistics Service of Ukraine. Its main practical purpose is to justify the socio-economic development policy. The method involves the use of an integral indicator formed based on the assessment of health care, reproduction of the population, social status, comfort of life, etc. The disadvantage of this methodology is the lack of 
the fiscal component assessment. In general, this technique is aimed at assessing human potential, which is explained by its niche nature.

At the state level, the Ministry for Communities and Territories Development of Ukraine has formulated a methodology to rate the socio-economic development of regions based on an integral indicator, which is calculated quarterly by 27 indicators in six directions and annually by 64 indicators in 12 directions. The methodology is aimed at identifying the reserves for the region competitiveness growth and ensuring their prospective socio-economic development. The advantages of the methodology are the use of financial self-sufficiency indicators (the amount of local budget revenues, the amount of capital expenditures, etc.); indicators of economic efficiency (industrial production index, consumer price index), economic and social cohesion metrics (GDP per capita), and investment and innovation indicators (capital investment index, export volume of goods).

Zhilenkova (2005) has formed a methodology for selecting the socio-economic development indicators. The approach's advantage is in its focus on the need to use economic indicators, since the resource approach is an important component of ensuring the balanced functioning of a region. Provided that the financial support of the regions is sufficient, the social policy is effectively implemented. According to the research, the constituents of regional economic development should be given the main attention through mechanisms of establishing a higher weighting factor when calculating the integral index of socio-economic development of regions.

Matrosova and Prudnikov (2008) comprehensively analyzed the methods for assessing the socio-economic development of regions. They considered rating evaluation, calculating the integral index, and hierarchy analysis. The advantage of the methodology for rating the socio-economic development of regions is the ability to reveal more developed regions and to understand the directions of identifying disparities in the development of regions; this contributes to a development strategy based on data calculated. A significant drawback of the rating is the use of general ranking, which reflects only arithmetic mean values of the studied indicators and does not classify them into financial, economic, social, industrial, etc.

The methodology for calculating the integral index is based on a taxonomic indicator of the development level, which is a synthetic value equal to all indicators that characterize the region's socio-economic policy. Comprehensive assessment of the socio-economic development of the regions allows identifying key problems of the region, comparing them with other regions and formulating a regional development strategy. The methodology's weakness is due to the heterogeneity of regions in terms of economic development and differentiation of socio-economic activities, which leads to incorrect comparison of different regions.

A hierarchy analysis is used to assess the state of socio-economic development of regions through mechanisms of selecting the most significant groups of socio-economic climate indicators, as well as within groups of indicators. The advantage of the methodology is in selecting the most important data for the socio-economic development of the regions from a large number of experts. The disadvantage is the compensatory nature of the lack of one indicator at the expense of another.

A common disadvantage of all the methods considered is the average combination of input and output indicators without taking into account their specific weight. Besides, at the local level, the policy pursued by the local administration plays a key role in the degree of socio-economic development, which is difficult to take into account in the methods considered.

Having generalized the socio-economic development techniques, one can highlight common features, in particular, the prior use of integral assessment of socio-economic development of regions, the use of several groups of indicators, the emphasis is put on indicators that are easy to evaluate, and budget and financial indicators are included in most assessment methods.

In today's context, scientific views are increasingly turning to the role of civil society as a driving force for changes in socio-economic development, since partnerships between government and civil society potentially create better conditions for regional 
development. Given that scientific developments in the area of public finance transparency contain a considerable range of issues, the purpose of creating a transparent budgetary environment is to ensure the optimal functioning of local self-government to achieve a high level of socio-economic development of the regions. The study highlights several key areas that are revised in the Literature Review section, which has form its own vision of how research is conducted.

Tikhomirova (2015) analyzed the transparency of budgets of different countries worldwide, compared different methods of assessing the transparency of budget policy entities, and made recommendations for Ukraine on improving tax and budgetary transparency. Shkolnyk, Melnyk, and Mershchii (2018) proposed a scientific and methodological approach to assessing the level of financial decentralization and made recommendations on improving the budget process transparency. Bukhtiarova, Dukhno, Kulish, Kurochkina, and Lypchanskyi (2019) developed a methodology for assessing the transparency of public finance in Ukraine. Based on the index of transparency of public finance management bodies, they calculated the percentage of data openness published by the Ministry of Finance of Ukraine and the State Fiscal Service of Ukraine. Khagram, Fung, and de Renzio (2013) and Alt and Lassen (2006) examine various aspects of tax transparency and its correlation with local government activities. Transparency studies in IMF projects were also conducted by Hameed (2005) and Arbatli (2012) who explored the effects of increasing public authorities' openness on increasing the international lenders' trust in international credit assistance recipients. Belousov and Timofeeva (2017) analyzed the problem of creating a mechanism for involving the citizens in the budget process as a way of increasing the efficiency of public financial management. The authors also considered a methodological approach to estimating the budget openness index.

Thus, a wide range of public finance studies in relation to transparency opens up new avenues for addressing current socio-economic needs of the regions. The rapid change in public finances raises the need to implement advanced transparency-based mechanisms for managing local finance.
The balanced work of local authorities and the public can ensure sustainable social and economic development of regions. Further research is at the intersection of different areas, in particular, public finance, transparency, and sustainable social and economic development.

\section{METHODS}

The state of socio-economic development of the regions is proposed to be estimated using an algorithm that involves the construction of an integral indicator of socio-economic development. Five indicators were selected for the assessment: the amount of capital investment by region, the volume of products sold in the regions, gross regional product, the average monthly wage in the region, and the economically active working age population in the region. The study stresses the importance of selecting each of these indicators of regional socio-economic development.

The indicator of economically active population by region indicates the potential level of economic capacity at the expense of labor resources in the region. The average monthly wage point to the satisfaction level of the citizens' needs at the expense of labor incomes, and the growth of the average level of income of the population potentially indicates the increasing degree of socio-economic development of a particular region. The volume of gross regional product characterizes the degree of the region development, expressed in terms of total gross value added from all types of economic activity. The volume of sales of products (goods, services) of enterprises reveals the economic capacity of the region to compete with other regions. The amount of capital investment indicates the economic attractiveness of the region and the potential for increasing its economic development.

The review of methods for assessing the state of socio-economic development of the regions gave reason to choose an algorithm for constructing an integral indicator as an expression of the state of socio-economic development in a particular region. The advantage of this algorithm is in generalizing heterogeneous indicators by nature, which enables to identify key problems of the region, compare them with other regions and give 


\begin{tabular}{|c|c|}
\hline \multicolumn{2}{|c|}{ Stage 1. Selection of socio-economic development indicators } \\
\hline $\begin{array}{l}\text { Stage 2. Indica } \\
P_{q i}^{H}=\frac{P_{q i}}{\max _{q}\{P}\end{array}$ & $\begin{array}{l}\min _{q}\left\{P_{q i}\right\} \\
-\min _{q}\left\{P_{q i}\right\}\end{array}$ \\
\hline $\begin{array}{l}P_{q i}^{H}-\text { normalized row value; } \\
P_{q i}-\text { current row value; }\end{array}$ & $\begin{array}{l}\max _{q}\left\{P_{q i}\right\} \quad \text { - maximum row value; } \\
\min _{q}\left\{P_{q i}\right\} \quad \text { - minimum row value. }\end{array}$ \\
\hline $\begin{array}{l}\text { Stage 3. Calculation of integral asses } \\
\qquad R=P_{q i 1}^{H}+P\end{array}$ & $\begin{array}{l}\text { ient of socio-economic development } \\
+\ldots+P_{\text {qin }}^{H}\end{array}$ \\
\hline where $R$-integral assessment of socio-economic & elopment. \\
\hline Stage 4. Determining the margins of the level of so & -economic development using the Sturges' formula \\
\hline 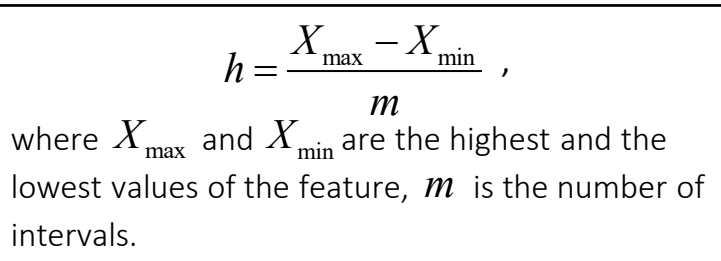 & $\begin{array}{l}\qquad m=1+3.322 \log (n) \text {, } \\
\text { where } m \text { is the number of intervals, } n \text { is the } \\
\text { sample volume. }\end{array}$ \\
\hline
\end{tabular}

Figure 1. An algorithm for integral estimation of the socio-economic development of a region

proposals to improve the future state of socio-economic development of the region.

The study period was 2016-2018. The assessment was conducted in 22 regions of Ukraine, except for the territories of Donetsk and Luhansk regions, due to differences in the completeness of the provided statistical information. The algorithm for calculating the integral index includes several steps. The methodology can be visualized as follows (see Figure 1).

The first stage forms the statistical base of selected indicators of the regions' socio-economic development. In the second stage, the selected indicators are normalized to bring them to a comparable form. Indicators are normalized using the absolute normalization formula. In the next step, each of the normalized indicators for a particular observed object is reduced to an integral indicator of the socio-economic development of a region for a certain year. To achieve that, the additive convolution method is used, since each of the selected indicators is assumed to have a linear and equal impact on the process under study. Stage four involves the use of the Sturges' rule. This method enables to determine the optimal number of ranking intervals based on the formula for determining the number of intervals and depending on the sample size (maximum and minimum values). Given the current sample, it is determined that five is the optimal number of ranking intervals of regions by the level of socio-economic development.

\section{RESEARCH RESULTS}

After calculations, consolidated estimates of the socio-economic development of Ukrainian regions were determined, which allowed them to be divided into five groups relative to the level of the studied indicator. 
Table 1. Region grouping by the level of socioeconomic development for 2016-2018

\begin{tabular}{l:c:c}
\hline $\begin{array}{c}\text { The level } \\
\text { of socio- } \\
\text { economic } \\
\text { development }\end{array}$ & $\begin{array}{c}\text { Estimate } \\
\text { interval }\end{array}$ & Region \\
\hline Low & {$[0.14 ; 2.86)$} & $\begin{array}{c}\text { Volyn, Zhytomyr, } \\
\text { Zakarpattia, Ivano- } \\
\text { Frankivsk, Kirovohrad, Rivne, } \\
\text { Sumy, Ternopil, Kherson, } \\
\text { Khmelnytskyi, Cherkasy, } \\
\text { Chernivtsi, Chernihiv }\end{array}$ \\
\hdashline Sufficient & {$[2.86 ; 5.58)$} & $\begin{array}{c}\text { Vinnytsia, Mykolaiv } \\
\text { Medium }\end{array}$ \\
\hdashline Increasing & {$[5.58 ; 8.30)$} & $\begin{array}{c}\text { Zaporizhzhia, Lviv, Odesa, } \\
\text { Poltava, Kharkiv }\end{array}$ \\
\hline High & {$[8.30 ; 11.02)$} & Kyiv \\
\hline
\end{tabular}

The results show that Ukraine's regions are not distributed equally in terms of socio-economic development. It should be noted that the high and increasing level groups of socio-economic development included only Kyiv and Dnipropetrovsk regions; this indicates that there are high disparities in the context of the phenomenon under study. Looking at the group of low socio-economic development, one can see that it is represented by 13 regions, which is the largest number. The second group by the number of regions is that of medium socio-economic development, which includes five regions. This division of regions into socio-economic development groups provides a general understanding of the current picture but does not characterize changes in dynamics.

The Transparent, Financially Healthy and Competitive Municipalities project, which performs a large-scale assessment of local self-government transparency, is the most comprehensive study of transparency across Ukrainian regions. This organization's transparency rating is based on the combination of several methods for gathering information: questionnaires, information in public domain, both from official sites of local self-government bodies and from profiles of regional councils on social networks. The main research areas are information policy, budget, public procurement, property management, social services, personnel policy, professional ethics and conflict of interest, citizen participation, media. That is, the study covers the main areas of transparency of local authorities. Generalized transparency scores range from 0 to $100 \%$. Studies conducted in the regions are published for 2017 and 2019.

The results of the best practices of this organization were used in the context of regional transparency to compare them with the calculated estimates of the regional socio-economic development. To do this, Table 2 identifies the rank of the object under study in terms of socio-economic development and transparency.

Table 2. Distribution of regions by level of socioeconomic development and transparency

\begin{tabular}{|c|c|c|c|c|c|}
\hline \multirow[t]{3}{*}{ Region } & \multirow{2}{*}{\multicolumn{3}{|c|}{$\begin{array}{c}\begin{array}{c}\text { Indicator of } \\
\text { social-economic } \\
\text { development* }\end{array} \\
\text { Position }\end{array}$}} & \multirow{2}{*}{\multicolumn{2}{|c|}{$\begin{array}{r}\begin{array}{r}\text { Transparency } \\
\text { indicator** }\end{array} \\
\text { Position } \\
\end{array}$}} \\
\hline & & & & & \\
\hline & 2016 & 2017 & 2018 & 2017 & 2019 \\
\hline Vinnytsia & 9 & 9 & 8 & 16 & 3 \\
\hline Volyn & 17 & 17 & 16 & 8 & 4 \\
\hline Dnipropetrovsk & 1 & 1 & 1 & 9 & 14 \\
\hline Zhytomyr & 16 & 14 & 14 & 14 & 21 \\
\hline Zakarpattia & 14 & 12 & 11 & 11 & 13 \\
\hline Zaporizhzhia & 6 & 6 & 6 & 2 & 5 \\
\hline Ivano-Frankivsk & 11 & 11 & 12 & 9 & 8 \\
\hline Kyiv & 2 & 2 & 2 & 18 & 7 \\
\hline Kirovohrad & 19 & 19 & 18 & 1 & 17 \\
\hline Lviv & 5 & 5 & 4 & 11 & 12 \\
\hline Mykovaiv & 8 & 8 & 9 & 5 & 18 \\
\hline Odesa & 4 & 4 & 5 & 14 & 6 \\
\hline Poltava & 7 & 7 & 7 & 11 & 19 \\
\hline Rivne & 13 & 16 & 17 & 4 & 1 \\
\hline Sumy & 15 & 15 & 15 & 6 & 9 \\
\hline Ternopil & 21 & 21 & 21 & 19 & 10 \\
\hline Kharkiv & 3 & 3 & 3 & 2 & 14 \\
\hline Kherson & 20 & 18 & 20 & 19 & 20 \\
\hline Khmelnytskyi & 12 & 13 & 13 & 16 & 2 \\
\hline Cherkasy & 10 & 10 & 10 & 7 & 16 \\
\hline Chernivtsi & 22 & 22 & 22 & 21 & 22 \\
\hline Chernihiv & 18 & 20 & 19 & 22 & 10 \\
\hline
\end{tabular}

Note: * calculated by authors; ** calculated by the Transparent, Financially Healthy and Competitive Municipalities project.

The results allow evaluating the dynamics of change in the studied indicators by comparing the place in the ranking. To confirm previous results, it was noted that Dnipropetrovsk, Kyiv, and Kharkiv regions ranked highest in the rating of socio-economic development, while Kherson, Ternopil, and Chernivtsi regions showed the lowest levels. Considering the dynamics of the change in the regions' positions by the socio-economic development level, it is evident that most of the objects observed were stable in terms of place occupied. 
The results of the transparency assessment, in contrast to the socio-economic development indicator, showed a significant change in the positions of regions from year to year. Over the period from 2017 to 2019, Khmelnytskyi (+14), Vinnytsia (+13), Chernihiv (+12), and Kyiv (+11) showed highest trends in their transparency, while Kirovohrad (-16), Mykolaiv (-13), Kharkiv (-12), and Cherkasy (-9) demonstrated significant decrease in this regard. Changes in current information policy in the area, covering information policy, budgetary data, public budgeting and other areas of openness of public authorities' information on the official web-resources are among key reasons for significant changes in the level of transparency in these areas.

Zaporizhzhia and Rivne ranked high in terms of budget transparency, while Kherson and Chernivtsi regions showed a stable low position during the period under study.

Comparing the ranks by the level of regions' socio-economic development and by the transparency level shows that the level of socio-economic development of regions often does not correspond to the transparency level. For example, significant deviations were observed in Dnipropetrovsk, Kyiv, Poltava, and Rivne regions. Meanwhile, Chernivtsi, Kherson, and Zakarpattia regions showed the approximate coincidence of the occupancy. The trends obtained show that the creation of an environment transparent to the local population rests solely with the local authorities who make their decisions regarding the importance of publishing socially important information on official resources. However, if sufficient attention is paid by local authorities to full and regular disclosure of budget information, the level of transparency in the regions will increase.

Assessing the transparency in terms of releasing important information is an important component of informing the public about the state of affairs in their region. However, the amount of budget information released may not meet the population needs, or the local population may not be interested in the state of the local budget. To this end, there was a need for further local public transparency studies. The questionnaire survey was chosen as a tool for local transparency. Sumy region was chosen for re- search. The questionnaire included eight multiple choice questions. The main purpose was to find out the real level of the population awareness of the local budget and to reveal the most effective information channels. In November 2019, 210 respondents took part in the survey. Respondents were the general public, business representatives, government officials and local governments. The survey was conducted using the Google Forms online tool. The sample size of 200 persons meets the survey needs: $85 \%$ confidence interval, $+/-5 \%$ error interval, and the general population of respondents (Sumy city population) is 264 thousand people. Table 3 summarizes the questions.

Table 3. Public finance transparency assessment questionnaire in 2019

\begin{tabular}{|c|c|}
\hline No. & Questions \\
\hline 1 & $\begin{array}{l}\text { Are you satisfied with the quality of reporting on your } \\
\text { local budget? }\end{array}$ \\
\hline 2 & $\begin{array}{l}\text { What are the most effective channels for informing the } \\
\text { population about local government activities? }\end{array}$ \\
\hline 3 & $\begin{array}{l}\text { Do you use the websites of local authorities (regional } \\
\text { government department, city council) or state } \\
\text { institutions (the State Fiscal Service, the National Bank of } \\
\text { Ukraine, etc.) to search for financial information? }\end{array}$ \\
\hline 4 & $\begin{array}{l}\text { Are you aware of the revenue structure of your local } \\
\text { budget? }\end{array}$ \\
\hline 5 & $\begin{array}{l}\text { Are you satisfied with the ways of using local budget } \\
\text { funds? }\end{array}$ \\
\hline 6 & $\begin{array}{l}\text { Do you know about the possibility of attending public } \\
\text { hearings in the budgeting process? }\end{array}$ \\
\hline 7 & Are you aware of the existence of public budget? \\
\hline 8 & $\begin{array}{l}\text { What is your reading of the mechanism of generating } \\
\text { budget revenues and expenditures? }\end{array}$ \\
\hline
\end{tabular}

The first question shows the city dwellers' satisfaction degree with budget information disclosure. The quality of the budget information received was suggested to be rated from 0 to 4 points. The largest number of respondents, 31.9\% (67 persons), showed complete dissatisfaction with the quality of reporting budget information in Sumy, which corresponds to 0. Approximately equal results were obtained from estimates of $1-24.8 \%$ (52 persons) and $2-28.1 \%$ (59 persons); this means that most respondents rate the quality of local budget reporting as low and medium. High ratings of satisfaction with the quality of information coverage were shown by a small number of respondents: an estimate of $3-12.4 \%$ (26 people) and $4-2.9 \%$ (6 people). Overall, $84.8 \%$ of respondents considered the current way of reporting budget information to local authorities inadequate for their needs. 
The second question is aimed at showing the real picture of the effectiveness of public information channels as to the local authorities' performance. The results show that modern public information channels from local authorities are needed today, as $56.7 \%$ (119) of respondents prefer social networks (Facebook, Twitter, etc.). The official sites of local governments ranked second, 27.1\% (57). Official sites are now the main channel of information for the population, but for the common user, social networks are becoming a convenient and main channel of getting information about the city's public life. The smallest proportion of respondents, $16.2 \%$ (34), choose traditional media (newspapers, local television, radio, banners, etc.) as a means of informing the public about local government activity. That is, in total, $83.8 \%$ of respondents receive information from digital sources.

The third question is to clarify the respondents' experience in finding the necessary financial information on official websites of local authorities or state institutions. It is found that most respondents occasionally use the official resources of local authorities or government institutions to search for financial information. The proportion of respondents who regularly use official resources to search for financial information is $16.7 \%$. $18.6 \%$ of respondents were unable to find the information they needed on official websites. Meanwhile, $20.5 \%$ do not use official resources for various reasons. In other words, official websites of local authorities and public institutions remain the preferred source to work with financial information; this confirms the need to further improve the data sharing mechanism, increase the transparency and improve the usability mechanisms.

The fourth and fifth questions are aimed at determining the local population awareness of the revenue-expenditure structure of the local budget. The results show that $32.4 \%$ of respondents are fully unaware of the local budget revenue structure, while approximately the same number of people surveyed gave the 1-3 awareness level. The assessments of the satisfaction with the ways of using local budget funds indicate that $41 \%$ of people were on average satisfied with the use of the city budget funds. $7.2 \%$ of respondents gave above average scores, which indicates an insufficient satisfaction of the local community needs. $24.8 \%$ estimate the current structure of local budget expenditures at the lowest level, which clearly indicates the general underfunding of the ways the community needs.

Public involvement in the budget process various stages is an important component of increasing transparency. Creating public budget that expresses the citizens' needs and interests is the basis for increasing the community involvement in addressing urgent needs. Public participation mechanisms are still in the early development, but there are real examples of involving the citizens in hearings on budgeting and public control over the public fund use. Community direct involvement in public budgeting is currently at the $4.3 \%$ level; however, $58.1 \%$ of the respondents are informed about the existence of public hearings in the budgeting process. Some of the population follow the discussion process, but for some reasons, they are not interested in personally participating in their community budgeting. Further steps should be in the area of developing convenient mechanisms for citizen participation in voting for budget initiatives, such as online voting, open public debates with the participation of authority representatives, briefings, etc. That is, the local financial authorities should create an atmosphere of cooperation and interest in the community wishes when formulating separate directions for financing local development. The Sumy resident survey indicates that $24.8 \%$ of the population are not aware of the existence of a public budget; $67.6 \%$ of respondents are at different awareness levels. $7.6 \%$ of respondents participated directly in public budget initiatives.

The active advertising campaign helped involve the city of Sumy in the creation, voting and implementation of its own projects through a special Community Project platform, which allows any resident to offer initiatives to improve the life of the city, which are realized at the expense of budget funds. For example, in 2018, 90 projects worth UAH 66 million were submitted for consideration in Sumy. The main public budget projects are implemented in energy saving, urban improvement, culture and tourism, education, healthy lifestyle. In 2017, ten community projects were implemented in Sumy. 
Table 4. Results of Sumy city transparency assessment for 2017-2019, \%

\begin{tabular}{|c|c|c|c|}
\hline \multirow{2}{*}{ Area } & \multicolumn{3}{|c|}{ Year } \\
\hline & 2017 & 2018 & 2019 \\
\hline Overall score & 64 & 72 & 73 \\
\hline Information policy & 70 & 77 & 80 \\
\hline Disposal of territorial community property & 67 & 67 & 71 \\
\hline Land use and construction policy & 42 & 42 & 67 \\
\hline Government procurement & 33 & 58 & 8 \\
\hline Budgeting process & 86 & 93 & 82 \\
\hline Administrative, housing, and social services & 67 & 80 & 93 \\
\hline Professional ethics and conflict of interest & 44 & 67 & 78 \\
\hline Personnel policy & 60 & 60 & 100 \\
\hline Citizen participation & 79 & 75 & 81 \\
\hline
\end{tabular}

The questionnaire asked people about the impact of openness of the mechanism for forming the budget revenues and expenditures on corruption. According to the results, $54.3 \%$ of respondents believe that public authority openness and understanding the mechanism of budget revenue-expenditure formation reduce corruption; $42.4 \%$ believe that this has no impact on the level of corruption. Only $3.3 \%$ say that openness increases the level of corruption.

The literature review shows that openness of local authorities to the public, combined with public control mechanisms, is a key to reducing corruption as evidenced by international practice.

Table 6 considers and summarizes the results of assessing openness of the city of Sumy based on the Transparent, Financially Healthy and Competitive Municipalities project.
The results are evaluated as a percentage of points scored from the maximum possible score. According to the survey, the overall estimate of the city budget transparency increases annually, which indicates the gradual incorporation of best practices in transparency. The 2019 budget area ranked lowest in the study period because of lack of information on local borrowings and local budget loans. The highest scores were given to the transparency in personnel policy, administrative, housing and social services. The Sumy public procurement sector has received the lowest transparency ratings because it requires improved disclosure of Sumy city council procurement information and ongoing procurement through Prozorro. Prospects for increasing the current transparency level of the city of Sumy in the areas under discussion are subject to public needs and practical implementation of the relevant information policy.

\section{CONCLUSION}

To conclude, the algorithm for integral assessment of the socio-economic development of a region is important from a practical perspective, since it allows characterizing key region's problems, comparing them with other regions and developing a strategy for regional development. Comparison of the estimates of the regions' socio-economic development and metrics of their transparency showed the discrepancy between the comparative estimates. The results obtained are due to the fact that creating a transparent budgetary environment depends on the regional information policy, which is formed by local authorities. The budget transparency survey of Sumy city showed the following average trends: $84.8 \%$ of the respondents said that the current state of budgetary transparency did not meet their needs; $56.7 \%$ of the population used social networks as the preferred source of budget information. Regular users of official information resources of local (state) authorities in search of financial information made up 16.7\%. More than a third (32.4\%) of the respondents had low awareness of the local budget revenue structure. Transparency analysis of the Sumy city budget for 2017-2019 showed the possibility of improving the results if the public information policy of the local authorities is applied to the public. 
The proposed methodology for assessing the socio-economic development of the regions is not exhaustive and can be modified according to the needs of the study. The list of questions selected for the fiscal transparency survey can be adapted to the specifics of the region being studied. Further scientific developments will be aimed at improving methodologies for studying the current state of transparency of local authorities regarding their socio-economic development.

\section{ACKNOWLEDGMENT}

The investigation was conducted within the state budget research of the Sumy State University 0118 U003585 "Forming the system of public finance transparency as a prerequisite for combating corruption in Ukraine."

\section{REFERENCES}

1. Alt, J. E., \& Lassen, D. D. (2006). Transparency, Political Polarization, and Political Budget Cycles in OECD Countries. American Journal of Political Science, 50(3), 530-550. https://doi.org/10.1111/ j.1540-5907.2006.00200.x

2. Arbatli, E. (2012). Fiscal Transparency, Fiscal Performance and Credit Ratings (IMF Working Paper, WP/12/156). https://doi. org/10.5089/9781475504477.001

3. Artemenko, V. (2002). Metody intehralnoi otsinky yakosti zhyttia naselennia $\mathrm{v}$ upravlinni rehionalnym rozvytkom [Methods of integral estimation of quality of life of population in management of regional development]. Rehionalna ekonomika - Regional economy, 1, 166-177. (In Ukrainian).

4. Artemenko, V. (2005). Modeliuvannia kompleksnykh otsinok efektyvnosti sotsialno-ekonomichnoho rozvytku rehioniv u konteksti kryteriiv yakosti zhyttia naselennia [Modeling complex efficiency assessments socio-economic development of the regions in the context of the living quality criteria]. Visnyk UN - TU - Bulletin UN - TU, 10, 59-70. (In Ukrainian). Retrieved from http://visnyk-ami.lnu.edu. ua/db/246/765/21.pdf

5. Babayev, V. M., \& Bychenko, L. A. (2011). Rehionalnyi ekonomichnyi rozvytok v konteksti provedennia ekonomichnykh reform v Ukraini [Regional Economic Development in the Context of Economic
Reforms in Ukraine]. Ekonomichnyi Chasopys-XXI - Economic Journal-XXI, 1(2), 20-22. (In Ukrainian). Retrieved from http:// dspace.nbuv.gov.ua/bitstream/ handle/123456789/32018/06Babayev.pdf? sequence $=1$

6. Belousov, Yu., \& Timofeeva, O. (2017). Budget Transparency Ranking of Russian Constituent Entities as a Tool to Improve Public Finance Management Effectiveness. Public Administration, 4, 139-157. Retrieved from https://ideas.repec.org/a/nos/ vgmu00/2017i4p139-157.html

7. Bukhtiarova, A., Dukhno, Y., Kulish, G., Kurochkina, I., \& Lypchanskyi, V. (2019). Ensuring transparency of key public finance authorities. Investment Management and Financial Innovations, 16(2), 128-139. http://dx.doi. org/10.21511/imfi.16(2).2019.11

8. Data and Statistical Services (n.d). Getting Started in Data Analysis using Stata and $R$. Retrieved from http://dss.princeton.edu/training

9. Golikov, A. (2012). Suchasnyi stan ta perspektyvy rehionalnoi polityky v Ukraini [The current state and prospects of regional policy in Ukraine]. Formuvannia mekhanizmu rehionalnoho upravlinnia $\checkmark$ Ukraini: materialy naukovopraktychnoi konferentsii - Formation of the mechanism of regional governance in Ukraine: materials of scientific-practical conference, 22-24. (In Ukrainian).
10. Goncharova, L. I. (2009). Dotsilnist vprovadzhennia podatkovoho pasportu rehionu [Expediency of implementing the regional tax passport]. Visnyk Khmelnytskoho Natsionalnoho Universytetu - Bulletin of the Khmelnytskyi National University, 4(2), 287-289. (In Ukrainian). Retrieved from http:// journals.khnu.km.ua/vestnik/pdf/ ekon/2009_4_2/pdf/287-289.pdf

11. Gubani, G. G. (2011). Predicting regional development: analysis of problems and approaches to their solution. Sustainable Development Economy, 1, 30-94.

12. Hameed, F. (2005). Fiscal Transparency and Economic Outcomes (IMF Working Paper No. WP/05/225). Retrieved from https://www.imf.org/external/ pubs/ft/wp/2005/wp05225.pdf

13. Khagram, S., Fung, A., \& de Renzio, P. (Eds.) (2013). Open Budget. The Political Economy of Transparency, Participation, and Accountability. Washington D.C.: Brookings Institution Press. Retrieved from https://www.brookings.edu/ book/open-budgets-the-politicaleconomy-of-transparency-participation-and-accountability/

14. Kushnirchuk, Y. (2010). The excess tax burden optimization with the purpose of economic safety. The Scientific Bulletin NLTU of Ukraine, 20(11), 161-169. Retrieved from https://cyberleninka. ru/article/n/optimizatsiya-rivnyafiskalnogo-navantazhennya-zmetoyu-ekonomichnogo-ubezpechennya-derzhavi/viewer 
15. Matrosova, L. M., \& Prudnikov, L. O. (2008). Analiz metodyk otsinky sotsialno-ekonomichnoho rozvytku rehioniv [Analysis of Methods of Assessment of Socio-Economic Development of Regions]. Ekonomichnyi Visnyk Donbasu - Economic Bulletin of Donbass, 3, 69-72. (In Ukrainian). Retrieved from http://nbuv.gov.ua/ UJRN/ecvd_2008_3_12

16. Mikhailichenko, A. O. (2004). Perspektyvy rozvytku rehionu na osnovi vdoskonalennia sotsialnoekonomichnykh protsesiv [Prospects for the development of the region on the basis of improvement of socio-economic pro- cesses]. Zb. nauk. pr. Ternopilskoi akademii narodnoho hospodarstva - The Scientific Bulletin of Ternopil Academy of National Economy, 9, 304-305. (In Ukrainian).

17. Pavlov, V. I. (2007). Conceptual foundations of sustainable spatial development management. Bulletin of the Economic Science of Ukraine, 1(11), 119-124.

18. Shkolnyk, I., Melnyk, T., \& Mershchii, B. (2018). Transparency of the budget process as a prerequisite for financial decentralization in Ukraine. Public and Municipal Finance, 7(1), 12-20. https://doi. org/10.21511/pmf.07(1).2018.02
19. Shostak, L., \& Bondaruk, O. (2002). Sustainable development: strategy, priorities, indicators. Energy: Economy, Technologies, Ecology, 3, 13-20.

20. Tikhomirova, E. (2015). Transparency of the Budget of Ukraine: Methods of Evaluation of the US Department of State and International Budget Partnership. International Relations. Political Science, 5.

21. Zhilenkova, M. M. (2005). The scorecard of socio-economic development of Ukraine. Statistics of Ukraine, 4, 51-53. 